\title{
Evaluation of Public Policy Relating to Radio and Television Broadcasting: Social and Economic Issues
}

\author{
By Ronald H. Coase \\ Professor of Economics in the Law School
}

The paper which follows first appeared in Land Economics, Volume XLI, Number 2, 1965 and is reprinted here with the permission of the publisher and of the author. Professor Coase wishes it noted that the first published suggestion that radio frequencies be awarded to the highest bidders appeared in an unsigned student comment entitled "'Public Interest' and the Market in Color Television Regulation," 18 University of Chicago Law Review 802 (1951). The author of the comment was Mr. Leo Herzel, now a practicing lawyer in Chicago.

In the United States, an evaluation of public policy relating to radio and television broadcasting turns itself into an evaluation of the work of the Federal Communications Commission, the body which (together with its predecessor, the Federal Radio Commission), has regulated the broadcasting industry for over 37 years. The performance of the Federal Communications Commission (herein referred to as FCC) has not been such as to lead most students of its operations to express admiration for the way it handles its problems.

James M. Landis, in his Report on the Regulatory Agencies which he prepared for President-elect Kennedy and which was issued in December, 1960, had this to say:

The Federal Communications Commission presents a somewhat extraordinary spectacle. Despite considerable technical excellence on the part of its staff, the Commission has drifted, vacillated and stalled in almost every major area. It seems incapable of policy planning, of disposing within a reasonable period of time the business before it, of fashioning procedures that are effective to deal with its problems. The available evidence indicates that it, more than any other agency, has been susceptible to ex parte presentations, and that it has been subservient, far too subservient, to the committees on communications of the Congress and their members. A strong suspicion also exists that far too great an influence is exercised over the Commission by the networks.

If we turn from the work of the FCC to the product of the broadcasting industry - the programs which are broadcast, and these must play a central role in any appraisal of the performance of the industry - we find a chorus of adverse criticism, in which members of the FCC have joined. They proclaim the failure of the existing system. It was Chairman Newton Minow who referred to television programs as a "vast wasteland."

Such views as those expressed by Dean Landis and Chairman Minow no doubt contain much truth. But they seem to have been unaware of the reason for this poor performance. Dean Landis hoped that the inefficiencies of the FCC would be cured by the appointment of men who would give strong and competent leadership. $\mathrm{Mr}$. Minow seems to have looked for better programs as a 
result of changes to be made within the broadcasting industry itself. But it is my considered opinion that the task imposed on the FCC could not be handled efficiently by any organization, however competent, while no basic change in programming is conceivable within the existing structure of the broadcasting industry.

There are many aspects of the broadcasting industry which are outside the competence of an economist. But this is not an industry in the appraisal of which an economist has to take a back seat. The root cause of the poor performance of both the FCC and the American broadcasting industry is the result of the way in which two basic economic questions have been handled: these are the allocation of radio frequencies and the method of finance of the broadcasting industry. And I think it is precisely because these problems are economic that most observers of the industry (in general non-economists) have been unable to see what is wrong or to suggest adequate remedies.

The basis for the present regulation of the broadcasting industry is that it uses a scarce resource, the radio frequency spectrum. As Mr. Justice Frankfurter said in 1943 in the famous National Broadcasting Company case: "The facilities of radio are not large enough to accommodate all who wish to use them. Methods must be devised for choosing among the many who apply. And since Congress itself could not do this, it committed the task to the Commission." The FCC is seen as the necessary mechanism for choosing out of the many claimants those who are to be allowed to use radio frequencies. An economist can hardly be surprised at the nature of the problem (scarcity, after all, is his subject) but the conclusion that is drawn about the need for a Commission to solve the problem is not one to which an economist would give immediate assent. All resources (free goods excepted) are scarce. And yet the American economic system manages to work without having a Commission for each resource which is entrusted with the task of allocating that resource to those who are to be allowed to use it. It is true that if a zero-price were maintained for each resource (as it is for radio frequencies), demand would exceed supply and in the circumstances there would be need for some governmental body to decide who among the many claimants should be granted use of each resource. But of course, as we all know, scarce resources are normally allocated in the United States by means of the pricing mechanism and a price emerges which is sufficiently high to reduce demand to equal the available supply. The question is: why isn't this done in the case of the radio frequency spectrum?

The answer, extraordinary though it may seem, is that the possibility of using the pricing mechanism is something which never occurs to those responsible for policy concerning the use of the radio frequency spectrum. Mr. Doerfer, when Chairman of the FCC, said that it would be desirable to have a "mechanism whereby you could have an exchange of frequencies between government and non-government" without apparently realizing that the pricing system provided such a mechanism. And Mr. Frank Stanton, President of Columbia Broadcasting System, when asked in the course of a Congressional inquiry, whether it would not be desirable to dispose of television channels by awarding them to the highest bidder, could only reply that this was a "novel theory," as if he had not noticed how the rest of the American economic system operated and was under the impression that the Columbia Broadcasting System obtained the land, labor and capital it required as the result of allocations from various federal commissions. Of course, once it is assumed that use of the pricing mechanism is out of the question it is hardly surprising that there is general support for the allocation of the radio frequency spectrum by the FCC to private users, including state and local government. This is the source of the FCC's power, and its weakness.

What has emerged can best be envisaged by imagining a situation in which a Federal Land Commission (the FLC) was given control over all the land in the United States and was instructed to dispose of it to users without charge. The position then would be that land could be obtained from the FLC for nothing or it could not be obtained at all. In these circumstances, applications for land from business, industry and individual would pour in to the FLC. Existing users, who would gain no financial advantage from disposing of their land to others, would resist any attempt to dispossess them of the land they were using. The excess demand over supply for land in many parts of the country would be appalling. The reasons advanced by the various claimants as to why they needed the land would be compelling and, up to a point, true. Extensive hearings would be required to determine what use should be made of any piece of land. The purposes for which the land was required would have to be examined, the character, competence and financial qualifications of the various applicants investigated. When land was awarded for one purpose, continuing inspection would be required to make sure that the way the land was used had not been changed without first having obtained permission from the FLC. The question of what constituted a change of use would have to be determined. The purely administrative problems faced by the FLC would be prodigious. At the same time, the external pressures exerted on the FLC would be strong and unremitting. Business groups would oppose any change which exposed them to additional competition. Politicians would oppose proposed changes which would reduce the income of their constituents or their own influence (and sometimes they might even have regard to their own incomes). No business would have any interest in economizing in the use of its land. Changes in land-use would come about only with great difficulty and would depend 
to a large extent on land becoming valueless in existing uses. Economic growth in the United States would be slowed by the shortage of land and the problem would no doubt call for Presidential attention.

That such would be the consequences of the establishment of a Federal Land Commission is not, I think, open to serious doubt. It is my contention that similar consequences have resulted from the establishment of the FCC. The most detailed enquiries are conducted before a grant is made of a license for the operation of a broadcasting station. The procedures are costly and time-consuming. This is particularly true in comparative hearings in which the FCC often has to choose between claimants, each of whom seems to be about equally well qualified, and between whom therefore the choice has to be based on some quite trivial or even dubious consideration. It might perhaps be argued that at least the selective process, which pays attention to the character of the applicants and their devotion to the public interest, has had as a result the selection of broadcast station operators with unusually high moral standards. But I doubt whether this is true. It is hardly possible to maintain such a point of view after the revelations at the time of the quiz and payola scandals. I would not wish to argue that the ethical standards of those in the American broadcasting industry are lower than those found in the rest of American business. It is enough for my purpose that, in spite of the selective process, it is not obvious that they are significantly higher. This is not really surprising. Most people have presumably invested in the broadcasting industry because they thought it would be more profitable than any alternative investment open to them; and the list of occupations of broadcast station owners as published by the FCC shows them to represent a cross-section of American business. It is not clear to me that the character of broadcasting station owners would have been significantly different if the licenses had been awarded to the highest bidder.

But the present system is not objectionable merely because it is expensive and fails to achieve its professed objectives. The present system introduces rigidities which a pricing system would avoid. Any adjustment of radio frequency use depends on the approval of the FCC and cannot be secured as a result of negotiation between the parties concerned. It is not possible for an expansion of the broadcasting industry to take place by firms in that industry acquiring the use of additional radio frequency spectrum in the same way that they would acquire any additional land, or labor, or capital that they would need. And in this connection it is important to realize that the broadcasting industry uses only a small fraction of the radio frequency spectrum. Such an industry would normally find it easy to expand. But this is not so with the existing procedures. This may be illustrated by the fact that the FCC itself was not able to arrange for the television broadcasting industry to expand into the adjacent
VHF band (occupied by the military) at the same time releasing the UHF channels-which the broadcasting industry had not been able to use effectively-for military use. The situation was described by $\mathrm{Mr}$. Doerfer, when Chairman of the FCC, to a Congressional enquiry. After explaining that there was wasteful use of radio frequencies rather than a shortage, he continued: "That brings me back to where the FCC and the military begin to bargain back and forth for space ... The military says 'Yes, we can use the UHF for this, but to do so is going to cost a billion dollars.' My answer to that is going to be, 'Maybe it would be advisable to spend a billion to make $\$ 10$ billion in national wealth.' They say 'You go up to Congress and try to get the billion dollars to obsolete this equipment,' and we say, 'Well, that is part of your duty.' We go back and forth ..." It is clear that if the broadcasting industry had been able to pay for the additional channels which a shift of the military to UHF would have allowed, a sum of money would have become available which might well have been sufficient to cover the additional costs which the move would have imposed on the military. As it is, the solution adopted was to compel all set manufacturers to make sets able to receive programs in the UHF band, a solution which could well be much less satisfactory and more costly than the proposal favored by Mr. Doerfer.

There are two other aspects of the present method of allocating the radio frequency spectrum which I must mention. A station operator who is granted a license to use a particular frequency in a particular place may be granted a very valuable right, one for which he would be willing to pay millions of dollars and which he would be forced to pay if others could bid for the frequency. But in fact if he gets this grant from the FCC at all, he gets it for nothing. Not only that but, after a decent interval, he may dispose of his station and in fact, if not in law, sell the grant which the FCC gave him for nothing. This procedure results in an arbitrary enrichment of those private individuals who receive these favors from the FCC. The FCC, by its emphasis on the financial qualifications of the claimants, must inevitably tend to favor firms or individuals who are already financially well-endowed. The FCC is, in fact, engaged in an anti-poverty campaign for millionaires. Of course, it has been alleged that the ability of the FCC to grant such large financial favors leads to corruption, and these allegations have not always been without foundation. But in such a situation it is hardly surprising to find that there is suspicion of undue influence in one form or another. In ancient Rome it was said that Caesar's wife should be above suspicion. This is impossible with the FCC. All this would be changed if the FCC sold its grants to the highest bidder. This is not, of course, an unheard-of proposal. This is exactly what the government does with its grazing lands and other types of governmental property. Oil companies are not 
given rights to exploit oil and gas deposits for nothing.

So much for one unfortunate aspect of the present policy. There is another. If the choice between claimants is honestly made, it is inevitable that it should be made on the basis of programs promised and, when the time for renewal of the license arrives, on the basis of programs actually broadcast. According to the Communications Act, there must be no censorship of the programs. But if the FCC takes programs into account in its decisions, it is clear there is a real threat to freedom of speech and of the press. That the threat has not been more apparent has been due to the timidity or political wisdom of the FCC. But what this has meant is that in granting or renewing licenses the FCC has not paid much regard to the product of the industry, the program. This does not mean that members of the FCC have not attempted to influence programs. Speeches are constantly being made which suggest that if the industry does not do something to improve its programs, the FCC may have to take more positive action-this is what has been called regulation by the raised eyebrow. And since the FCC has many favors to give, I am sure that its wishes receive some consideration. But this is surely a matter for concern. This does pose a threat to freedom of the press. And yet there is good reason to be dissatisfied with the programs provided by the American broadcasting industry.

The American broadcasting industry itself presents a "somewhat extraordinary spectacle." It is financed by revenue from advertisements, a system commonly called commercial broadcasting. The essence of a commercial broadcasting system is that the operator of a radio or television station is paid for making broadcasts or allowing them to be made. But he is not paid by those who listen to or those who view the programs. He is paid by those who wish listeners to receive a particular message-the advertisement, or commercial. However, simply to broadcast the commercial will not usually lead people to listen or view. In a commercial broadcasting system the object of the program is to attract an audience for the commercials. It is not from the benevolence of the butcher, the brewer and the baker that we expect our radio and television programs. The programs are a by-product of the selling process.

In such a system, what programs will be broadcast? They are the programs which maximize the difference between the profits yielded by broadcast advertising and the costs of the program. A thorough examination of this system is obviously impossible here but I will indicate some of its consequences for the choice of program. Of two audiences of equal size, the one which is more responsive to advertising will always be preferred. In general, a large audience mildly interested will be preferred to a small audience intensely interested. The additional costs that will be incurred for programs will be limited to the profits on the additional sales of the advertised product that these additional program costs will bring. The result of all this is that commercial broadcasting leaves some sectors of the public with the feeling that they are not being catered to. And this is true. This is recognized by the FCC in its exhortations to the broadcasters. But such appeals, if they have any effect at all, bring only marginal changes in a structure of programming which is tied to the profitability of the commercials. No significant improvement in the present situation is to be expected unless the financial basis of the industry is changed. Businessmen do not pay $\$ 20$ million for a television station in order to use up their capital.

In the circumstances it might have been expected that the FCC would have welcomed the proposal for paytelevision. But welcome would be the wrong word to use to describe the response of the FCC. In dealing with paytelevision, to adopt Dean Landis' words, the FCC has "drifted, vacillated and stalled." Proposals for subscription television were made in the late 1940's and the early 1950 's; but it was not until 1959 that the FCC announced its detailed conditions-not for subscription television but for an experiment in subscription television. These conditions were highly restrictive. A given system could be tested only in a single city and then only in one in which there were at least four television stations. But this is not the place for a detailed discussion of FCC policy towards 
pay-television. Suffice it to say that only one such experiment has been started, that in Hartford, Connecticut. At present, of course, wire pay-television systems are outside the control of the FCC. But moves are afoot which would bring these also under FCC control.

It is often said that regulatory commissions are, in the end, captured by the industries which they regulate. There is much truth in this observation and the FCC is well on the way to providing us with another example. In spite of all the criticisms which the FCC itself makes, and notwithstanding the obvious faults of a commercial broadcasting system, the FCC is becoming a defender of that system. Competition must be rigidly controlled. $\mathrm{Mr}$. William Henry, the present Chairman of the FCC, said of the role of pay-television: "It must be a supplemental service, not a substitute service."

The time is not too late for the FCC to change its course. The present system, in which no use is made of the pricing system in the allocation of radio frequencies and in which consumers are barred from the market for programs, represents such an extreme position and is so different from what is found in other American industries, as to create a presumption that it is wrong. I have emphasized the need to introduce a market in radio frequencies and to improve the market for programs. But the policy choice should not be put in terms of government action versus the market in the field of radio and television. I am arguing for sensible government action. I am arguing for a properly functioning market. These aims are not inconsistent. Of course, the task of building social institutions is not an easy one. But it is not made easier by syrupy talk about broadcasters acting in the public interest. What is wanted is more economics and less humbug. 